\title{
RESEARCH
}

Open Access

\section{Cell migration inhibition activity of a non-RGD disintegrin from Crotalus durissus collilineatus venom}

Isadora Sousa de Oliveira ${ }^{1 \dagger}$, Rafaella Varzoni Manzini ${ }^{1 \dagger}$, Isabela Gobbo Ferreira ${ }^{1}$, lara Aimê Cardoso ${ }^{1}$, Karla de Castro Figueiredo Bordon', Ana Rita Thomazela Machado², Lusânia Maria Greggi Antunes², José Cesar Rosa ${ }^{3}$ and Eliane Candiani Arantes $^{1 *}$ (i)

\begin{abstract}
Background: In recent decades, snake venom disintegrins have received special attention due to their potential use in anticancer therapy. Disintegrins are small and cysteine-rich proteins present in snake venoms and can interact with specific integrins to inhibit their activities in cell-cell and cell-ECM interactions. These molecules, known to inhibit platelet aggregation, are also capable of interacting with certain cancer-related integrins, and may interfere in important processes involved in carcinogenesis. Therefore, disintegrin from Crotalus durissus collilineatus venom was isolated, structurally characterized and evaluated for its toxicity and ability to interfere with cell proliferation and migration in MDA-MB-231, a human breast cancer cell line.

Methods: Based on previous studies, disintegrin was isolated by FPLC, through two chromatographic steps, both on reversed phase C-18 columns. The isolated disintegrin was structurally characterized by Tris-TricineSDS-PAGE, mass spectrometry and N-terminal sequencing. For the functional assays, MTT and wound-healing assays were performed in order to investigate cytotoxicity and effect on cell migration in vitro, respectively.

Results: Disintegrin presented a molecular mass of $7287.4 \mathrm{Da}$ and its amino acid sequence shared similarity with the disintegrin domain of P-II metalloproteases. Using functional assays, the disintegrin showed low cytotoxicity ( $15 \%$ and $17 \%$, at 3 and $6 \mu \mathrm{g} / \mathrm{mL}$, respectively) after $24 \mathrm{~h}$ of incubation and in the wound-healing assay, the disintegrin $(3 \mu \mathrm{g} / \mathrm{mL})$ was able to significantly inhibit cell migration $(24 \%, p<0.05)$, compared to negative control.

Conclusion: Thus, our results demonstrate that non-RGD disintegrin from C. d. collilineatus induces low cytotoxicity and inhibits migration of human breast cancer cells. Therefore, it may be a very useful molecular tool for understanding ECM-cell interaction cancer-related mechanisms involved in an important integrin family that highlights molecular aspects of tumorigenesis. Also, non-RGD disintegrin has potential to serve as an agent in anticancer therapy or adjuvant component combined with other anticancer drugs.
\end{abstract}

Keywords: Crotalus durissus collilineatus, Non-RGD disintegrin, Cell migration, Cell adhesion, Human breast cancer, MDA-MB-231

\footnotetext{
* Correspondence: ecabraga@ffrp.usp.br

${ }^{\dagger}$ Isadora Sousa de Oliveira and Rafaella Varzoni Manzini contributed equally to this work

${ }^{1}$ School of Pharmaceutical Sciences of Ribeirão Preto, Department of Physics and Chemistry, University of São Paulo, Av. do Café s/nº, Monte Alegre,

Ribeirão Preto, SP 14040-903, Brazil

Full list of author information is available at the end of the article
}

(c) The Author(s). 2018 Open Access This article is distributed under the terms of the Creative Commons Attribution 4.0 International License (http://creativecommons.org/licenses/by/4.0/), which permits unrestricted use, distribution, and reproduction in any medium, provided you give appropriate credit to the original author(s) and the source, provide a link to the Creative Commons license, and indicate if changes were made. The Creative Commons Public Domain Dedication waiver (http://creativecommons.org/publicdomain/zero/1.0/) applies to the data made available in this article, unless otherwise stated. 


\section{Background}

Disintegrins are low-molecular-mass cysteine-rich peptides found in snake venom that comprise from 40 to 100 amino acid residues [1-3]. In 1987 Huang et al. observed that a small protein isolated from Trimeresurus gramineus venom, called "trigramin", presenting the arginine-glycine-aspartic acid (RGD) domain, was able to inhibit platelet aggregation, by preventing the connection between fibrinogen and platelets stimulated by ADP [3]. The term "disintegrin" was coined by Gould et al. when they demonstrated that the mechanism for inhibition of platelet aggregation was related to interaction between fibrinogen and $\alpha_{\mathrm{IIb}} \beta_{3}$ platelet integrins [4].

Most snake venom disintegrins are believed to be released by proteolytic processing of snake venom metalloproteases (SVMP) from the class P-II [1, 5]. Briefly, SVMP can be classified into three classes according to domain composition present in their structures: (i) P-I SVMP only contains a domain of metalloproteases; (ii) P-II SVMP has a metalloprotease domain and a disintegrin domain on its C-terminal tail, that can be released; (iii) and P-III SVMP contains a metalloprotease domain, a disintegrin-like domain and cysteine-rich domain [6].

Similarly to metalloproteases, disintegrins can also be classified according to their structure, considering the numbers of disulfide bonds and amino acid residues: (i) short disintegrins contain 41 to 51 amino acid residues, stabilized by 4 disulfide bonds; (ii) medium-sized disintegrins contain approximately 70 amino acid residues and 6 disulfide bonds; (iii) long disintegrins, with approximately 84 residues and 7 disulfide bonds; (iv) and the last group that comprises homo- and heterodimeric disintegrins, with approximately 67 residues per subunit, 4 intrachain disulfide bonds, in addition to 2 interchain cystine bonds, stabilizing the molecules [7-10].

In general, these molecules carry this name because they have the RGD motif in their primary amino acid sequence, which is capable of binding to integrins [4]. However, due to a mutation or a sequence of up to three mutations, other domains can be generated, also characterizing a disintegrin by inhibiting other types of integrins $[2,11]$. The classical RGD domain is capable of blocking $\alpha_{\text {IIb }} \beta_{3}, \alpha_{5} \beta_{1}, \alpha_{8} \beta_{1}, \alpha_{v} \beta_{1}$ and $\alpha_{v} \beta_{3}$ integrins, while the KGD domain inhibits integrin $\alpha_{\text {IIb }} \beta_{3}$ with high selectivity; WGD domain inhibits $\alpha_{\text {IIb }} \beta_{3}$, $\alpha_{5} \beta_{1}$, and $\alpha_{v} \beta_{3}$ integrins; MGD and VGD domains can affect the $\alpha_{5} \beta_{1}$ integrin function; KTS and RTS domains are inhibitors of $\alpha_{1} \beta_{1}$ integrin; MLD domain targets the integrins $\alpha_{3} \beta_{1}, \alpha_{4} \beta_{1}, \alpha_{4} \beta_{7}, \alpha_{6} \beta_{1}, \alpha_{7} \beta_{1}$ and $\alpha_{9} \beta_{1}$; and the adhesive function of $\alpha_{\text {IIb }} \beta_{3}$ can be blocked by the MVD domain [1214]. As an example, we can mention ussuristatin 2 Agkistrodon ussuriensis venom [15] and barbourin from Sistrurus M. barbouri [16], which lack the classical RGD domain, as well as atrolysin E from Crotalus atrox, from P-II SVMP, which possesses the MVD motif [17].
Due to this ability related to integrins, disintegrins also can be used for the therapy of vascular diseases and bacterial infections $\left(\alpha_{5} \beta_{1}\right)$, autoimmune diseases and inflammation $\left(\alpha_{4} \beta_{1}, \alpha_{7} \beta_{1}\right.$ and $\left.\alpha_{9} \beta_{1}\right)$, thrombosis and acute coronary syndromes $\left(\alpha_{\mathrm{IIb}} \beta_{3}\right)$, rheumatoid arthritis and osteoporosis $\left(\alpha_{\mathrm{v}} \beta_{3}\right)$, tumor angiogenesis $\left(\alpha_{1} \beta_{1}\right.$ and $\left.\alpha_{\mathrm{v}} \beta_{3}\right)$ and metastasis $\left(\alpha_{\mathrm{v}} \beta_{3}\right)$ [2]. Nowadays, there are two drugs approved by the Food and Drug Administration (FDA) whose design is based on two disintegrins isolated from snake venoms. Eptifibatide (Integrilin ${ }^{\circ}$ ) and Tirofiban $\left(\right.$ Aggrastat $\left.^{\circ}\right)$ were approved in 1998 and 1999, respectively, and are used for acute coronary syndromes because they target the $\alpha_{\text {IIb }} \beta_{3}$ integrin [18]. Eptifibatide is based on the KGD motif from barbourin, a disintegrin from Sistrurus miliarius barbourin [19], while Tirofiban is based on the RGD motif from echistatin, a disintegrin from Echis carinatus [20].

Integrins are closely related to the initiation, promotion and progression of tumors and metastasis [21]. Therefore, disintegrins may play an important therapeutic role as a potential anticancer drug, as is the case of contortrostatin [2]. Zhou et al. observed that this disintegrin from Agkistrodon contortrix contortrix venom was not able to cause cytotoxicity in MDA-MB-435 cells (human melanoma cells formerly classified as a human breast cancer cell line), and also prevented the binding of these cells to integrins $\left(\alpha_{\mathrm{v}} \beta_{3}\right)$ and extracellular matrix proteins, such as vitronectin and fibronectin, thus inhibiting the adhesion process [22]. There are many other examples of disintegrins that act as anticancer agents, such as saxatilin, from Gloydius saxatilis, which is capable of inhibiting the growth of tumors [23], leucurogin, from Bothrops leucurus, that has an anti-angiogenic effect [24] and the adinbitor, from Agkistrodon halys stejneger, which also inhibits angiogenesis both in vitro and in vivo [25]. Eritostatin, from Eristicophis macmahoni venom, was able to inhibit the migration of melanoma cells, an effect mediated by binding of fibronectin to integrins [26], whereas crotatroxin 2, from Crotalus atrox venom, inhibited cell migration of breast carcinoma cells [27]. Interestingly, cilengitide, a cyclic mimetic peptide that has affinity for $\alpha_{v} \beta_{3}$ and $\alpha_{v} \beta_{5}$ integrins, displays antiangiogenic action in low amounts. However, in phase III clinical trials, this drug did not show positive results for patients newly diagnosed with glioblastoma [28, 29]. There are also studies that evaluated the effects of disintegrins on individual stages of metastasis, including cell cycle arrest, extravasation and cell migration [21].

Snake toxins, including disintegrins, are attracting more interest in the fields of medicine and biotechnology. Based on that, this study reports the isolation and structural characterization of a non-RGD disintegrin from Crotalus durissus collilineatus, as well as its cytotoxic effect and functional role in the migration of MDA-MD-231 
human breast cancer cells, a highly metastatic cell line which is triple negative to progesterone and estrogen receptors [30, 31].

\section{Methods}

\section{Snake venoms}

Crotalus durissus collilineatus venom was provided by the Serpentarium at the School of Medicine of Ribeirão Preto, University of São Paulo, Brazil, accredited by Brazilian Institute of the Environment and Renewable Natural Resources (IBAMA), and registered under number 1506748 , for scientific purposes. All animals were adult and crotamine-negative. The extracted venoms were dried at room temperature for $6 \mathrm{~h}$ in a vacuum desiccator and stored at $-20{ }^{\circ} \mathrm{C}$ until use.

\section{Purification of disintegrin}

Disintegrin from $C . d$. collilineatus venom was purified through two chromatographic steps carried out in a Fast Protein Liquid Chromatography (FPLC) system (Äkta Purifier UPC 900, GE Healthcare, Uppsala, Sweden). The venom $(30 \mathrm{mg}$ ) was dispersed in $0.1 \%$ trifluoroacetic acid (TFA, solution A) and 1\% formic acid, and centrifuged at $13,000 \times g$ at $4{ }^{\circ} \mathrm{C}$ for $10 \mathrm{~min}$. The supernatant was fractionated on a C18 column $(250 \times 10 \mathrm{~mm}, 5 \mu \mathrm{m}$ particles, $300 \AA$, Phenomenex, Torrence, CA, USA) at a flow rate of $5 \mathrm{~mL} / \mathrm{min}$, using the concentration gradient described by Calvete et al. [32]. The second step was performed on another C18 column $(250 \times 4.6 \mathrm{~mm}$, $3.6 \mu \mathrm{m}$ particles, Phenomenex, Torrence, CA, USA) at a flow rate of $1 \mathrm{~mL} / \mathrm{min}$ and the proteins were eluted using a segmented concentration gradient from 6.3 to $100 \%$ of solution B $(80 \%$ acetonitrile, $\mathrm{ACN}$, in $0.1 \%$ TFA). In both steps, the protein elution was monitored by absorbance at $214 \mathrm{~nm}$. Fractions of interest were collected, frozen and lyophilized for further analysis.

\section{Mass determination}

The fractions of interest were analyzed by Tris-Tricine-SDS-PAGE (16.5\%) [33] under reducing conditions. The molecular mass markers of $97.0-14.4 \mathrm{kDa}(17-$ 0446-01, GE Healthcare) and 26.6-1.06 kDa (M3546-1VL, Sigma-Aldrich, Saint Louis, MO, USA) were used. Proteins were stained with $0.2 \%$ Coomassie Brilliant Blue G-250 (Sigma).

Also, the accurate molecular mass was determined by matrix-assisted laser desorption/ionization (MALDI) with time of flight (TOF) analyzer and Smartbeam II laser, an ultrafleXtreme instrument with the software FlexControl, version 3.3 (Bruker Daltonics GmbH, Leipzig, Germany) for the acquisition of data. The parameters employed to obtain the data were 500 laser shots per spectrum, $1000 \mathrm{~Hz}$ laser frequency and the instrument operating in positive reflected mode, within a range of 5 to $50 \mathrm{kDa}$, according to the manufacturer's instructions. UltrafleXtreme instrument was calibrated using a mixture of peptides (Peptide calibration standard, NC9846988) and proteins (Protein calibration standard I, NC0239984, and Protein calibration standard II, NC0416074) from Bruker Daltonics. A saturated solution of $\alpha$-cyano-4-hydroxycinnamic acid ( $\alpha$-CHCA) matrix was prepared in $\mathrm{ACN}$ and $0.1 \% \mathrm{TFA}(\mathrm{V} / \mathrm{V})$, at the ratio of 1:1 (V/V). Data analysis was performed by the software FlexAnalysis, version 3.3 (Bruker Daltonics GmbH, Leipzig, Germany).

\section{Protein identification}

For protein identification, the fraction of interest was submitted to N-terminal and MS/MS sequencings.

$\mathrm{N}$-terminal sequencing was performed by the Edman degradation method [34], using the automated protein sequencer model PPSQ-33A (Shimadzu, Kyoto, Japan), according to the manufacturer's instructions. The similarity of the amino acid sequences obtained in relation to sequences already deposited in databanks was evaluated by the Basic Local Alignment Search Tool (BLAST) [35].

The fraction of interest was reduced, alkylated, digested with sequencing grade porcine pancreatic trypsin and applied on a reversed phase C18 column $(0.075 \times 100 \mathrm{~mm}, 1.7 \mu \mathrm{m}$ particles, $130 \AA$, Waters, Manchester, UK) for ultra-performance liquid chromatography (UPLC) coupled to electrospray (ESI) mass spectrometer, with quadrupole-time of flight (Q-TOF) analyzer (API-US, Waters, Manchester, UK). Data were interpreted with a licensed version of the MASCOT program against databank protein sequence deposited in the SwissProt (554,241 sequences, 198,410,167 amino acid residues) database and a databank of protein sequences filtered for snake venoms (27,207 sequences, 10,540,234 amino acid residues), generated from UniProt Knowledgebase (UniProtKB) [36]. Precursor mass tolerance was $1.2 \mathrm{Da}$ and MS/MS mass tolerance was set to $\pm 0.8 \mathrm{Da}$, carbamidomethyl cysteine was set as fixed modification and oxidation of methionine as variable modification.

\section{Functional assays}

To verify whether the protein has cytotoxic activity and interferes with cell migration, two functional tests were carried out: cell viability assay by MTT and cell migration assay by wound healing in monoculture (MDA-MB-231). Human breast cancer cell line (MDA-MB-231), obtained from American Type Culture Collection (ATCC, Cat No. HTB-26), was cultured in Dulbecco's Modified Eagle's Medium (DMEM) medium supplemented with $4 \mathrm{mM} \mathrm{L-}$ glutamine, $10 \%$ fetal bovine serum and 1\% antibiotics (streptomycin, gentamycin and neomycin). Cells were maintained under standard conditions at $37{ }^{\circ} \mathrm{C}, 5 \% \mathrm{CO}_{2}$ and $95 \%$ humidity in a Forma Series II stove, Water Jacket 
$\mathrm{CO}_{2}$ Incubator (ThermoFisher Scientific, Waltham, Massachusetts, USA). All the experiments were conducted between the third and the eighth cell passage.

MDA-MB-231 cells were submitted to 3-[4, 5-dimethylthiazol-2-yl]-2, 5 diphenyl tetrazolium bromide (MTT) assay according to Mosmann [37]. Initially, MDA-MB-231 cells were seeded in 96-well culture plates at the density of $1 \times 10^{4}$ cells per well. Subsequently, the plates were incubated at $37{ }^{\circ} \mathrm{C}$ in $5 \% \mathrm{CO}_{2}$ for $24 \mathrm{~h}$. After the incubation time, the cells were treated with the toxin at concentrations of $0.75 ; 1.50 ; 3.00$; $6,00 \mu \mathrm{g} / \mathrm{mL}$. Phosphate buffered saline (PBS) was used as negative control, and methyl methanesulfonate (MMS) as positive control (300 $\mu \mathrm{M}$ or $33,039 \mathrm{mg} / \mathrm{L})$. After $24 \mathrm{~h}$ of treatment, $20 \mu \mathrm{L}$ of MTT solution $(5 \mathrm{mg}$ / $\mathrm{mL}$ ) was diluted in PBS and added to each well and the plate was incubated for $3 \mathrm{~h}$. After the incubation time, the plates were centrifuged for $5 \mathrm{~min}$ at $1027 \times g$, the supernatant removed and $200 \mu \mathrm{L}$ of dimethyl sulfoxide (DMSO) added. Absorbance reading was done at $570 \mathrm{~nm}$ using a microplate reader (Biotek EL800 Winooski, USA). The percentage of cell viability was obtained by the ratio between the absorbance of each treatment well and the absorbance of the wells of the negative control cultures, with cell viability considered $100 \%$.

For the wound healing assay, $3.0 \mu \mathrm{g} / \mathrm{mL}$ of disintegrin was used, and the assay was performed according to Liang, Park and Guan [38]. MDA-MB-231 cells $(1.5 \times$ $10^{5}$ cells/well) were grown to $90 \%$ confluence on a 12-well plate. Then, with the aid of a sterile tip, a cicatrix was performed on the adherent monolayer of tumor cells. The culture medium was changed to remove the cell debris and a new culture medium added containing the lowest concentration $(3.0 \mu \mathrm{g} / \mathrm{mL})$ of disintegrin which demonstrated effects on the cell line in the MTT assay and PBS as CN. Images of the wounds were recorded with a camera coupled to the inverted microscope at times $0,4,8$ and 24 h of incubation. The mean distance of the internal area was determined as the percentage migration using the software AxionVision according to the following equation:

$$
\text { Cell migration }(\%)=\frac{(A t=0 h)-(A t=24 h)}{(A t=0 h)} \times 100
$$

All the results were expressed as the mean \pm standard deviation (SD). Data from three independent experiments $(n=3)$ were statistically analyzed using the software GraphPad Prism 5 (La Jolla, CA, USA). After assessing normality of variable distributions using the Kolmogorov-Smirnov test, experimental data were analyzed using one-way analysis of variance (ANOVA) followed by Dunnett's test. Statistical significance was considered at $p<0.05$.

\section{Results \\ Purification and identification of non-RGD disintegrin}

Purification of disintegrin was performed in two steps, both on reversed phase $\mathrm{C} 18$ columns. The first step resulted in 22 fractions (Fig. 1a) and Fraction 2 was chosen for further analysis. In order to isolate the disintegrin, Fraction 2 was refractionated by reversed phase chromatography on a FPLC system with a segmented acetonitrile gradient represented by the dashed line in blue (Fig. 1b). The final chromatographic profile presented 10 fractions, with Fraction 6 being the major and most probable fraction where the disintegrin may have eluted, representing $0.43 \%$ of the total venom (Table 1 ).

The fractions of interest were analyzed by Tris-Tricine-SDS-PAGE (16.5\%). The electrophoretic profile revealed that Fraction 2 exhibits a protein band of apparent $7 \mathrm{kDa}$ molecular mass and some contaminants (Fig. 2a). After the second chromatographic step, it was possible to observe in Fraction 6 a single band of nearly $7 \mathrm{kDa}$ corresponding to disintegrin. Thus, it was possible to separate disintegrin from its contaminants of approximately $14 \mathrm{kDa}$, which eluted in fractions 7 and 8 . The molecular mass of the peptide present in Fraction 6 was determined by MALDI-TOF as 7287.402 Da (Fig. 2b).

The first 43 amino acid residues of the N-terminal region of the Fraction 6 were sequenced by Edman degradation and shared identity with others disintegrins (Fig. 3a). In addition, Fraction 6 was digested with trypsin and submitted to MS/MS sequencing. Data from obtained sequences are shown in Table 2.

As to the in silico analysis, it was observed that these sequences shared similarity with the disintegrin domain (amino acid residues 397 to 478) of metalloproteases PII from $C . d$. collilineatus (COL2T8) and $C$. $d$. durissus (Q2QA03), including the conservation of cysteine amino acid residues (Fig. 3a). Comparing the amino acid residues obtained from Fraction 6 with the primary sequences of both disintegrins, there was $76.8 \%$ coverage of the total sequence using Edman degradation and mass spectrometry procedures. In addition, these results show that the disintegrin of this study is a non-RGD disintegrin. The classic RGD motif, the conserved cysteine amino acid residues and the disulfide bond pattern commonly observed in disintegrins, as well as the determined sequence of Fraction 6 (LVN disintegrin) are shown in Fig. 3b for comparison purposes.

\section{Functional assays with non-RGD disintegrin}

Cell viability of MDA-MB-231 was determined in the presence of disintegrin; it was observed that the 

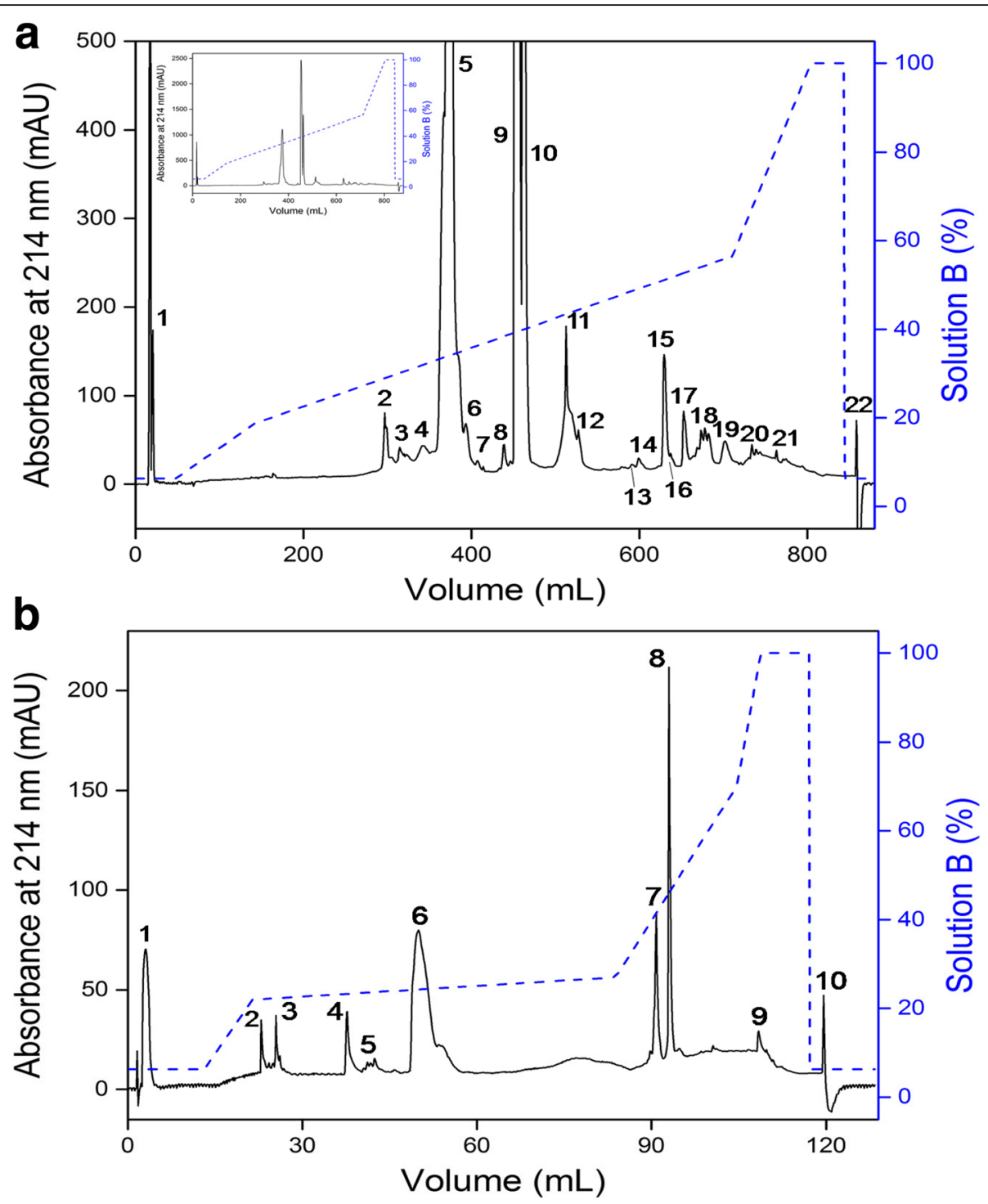

Fig. 1 Chromatographic profiles of non-RGD disintegrin from C. d. collilineatus venom using RP-FPLC system. a C. d. collilineatus venom (30 mg) was applied on a C18 column ( $250 \times 10 \mathrm{~mm}, 5 \mu \mathrm{m}$ particles, $300 \AA$ A), at a flow rate of $5 \mathrm{~mL} / \mathrm{min}$ and (b) Fraction 2 (200 $\mu \mathrm{g})$ on a C18 column ( $250 \times 4.6 \mathrm{~mm}, 3.6 \mu \mathrm{m}$ particles), at a flow rate of $0.5 \mathrm{~mL} / \mathrm{min}$. Elution in both chromatograms was carried out in a segmented concentration gradient from 6.3 to $100 \%$ of solution B ( $80 \%$ ACN in $0.1 \%$ TFA, represented by the blue dashed line) and absorbance was monitored at $214 \mathrm{~nm}$. Inset panel - whole chromatographic profile without magnification

concentrations of 3 and $6 \mu \mathrm{g} / \mathrm{mL}$ of disintegrin significantly decreased cell viability in approximately $15 \%$ and 17\%, respectively (Fig. 4a). Considering that disintegrin presented low yield in the purification steps $(0.43 \%$, Table 1) and that the two concentrations did not differ statistically ( $t$ test - data not shown), we chose to use the concentration of $3 \mu \mathrm{g} / \mathrm{mL}$ in the wound healing assay.

The cell migration assay based on wound healing showed that disintegrin was able to significantly inhibit cell migration of MDA-MB-231 (24\%, $p<0.05$

Table 1 Protein recovery (\%) during the purification procedure of disintegrin from Crotalus durissus collilineatus venom

\begin{tabular}{lll}
\hline Sample & Purification steps & ${ }^{\text {a Protein recovery (\%) }}$ \\
\hline Cdc venom & Venom solubilization & 100.0 \\
Fraction 2 & RP-FPLC on a C-18 column (1st chromatography) \\
Fraction 6 & RP-FPLC on a C-18 column (2nd chromatography) & 0.94
\end{tabular}

${ }^{a}$ The recovery percentage of each peak was calculated by the software Unicorn 5.2 (GE Healthcare) using the relation between the area under the curve of absorbance at $214 \mathrm{~nm}$ of the corresponding peak and the sum of the areas of all eluted peaks 

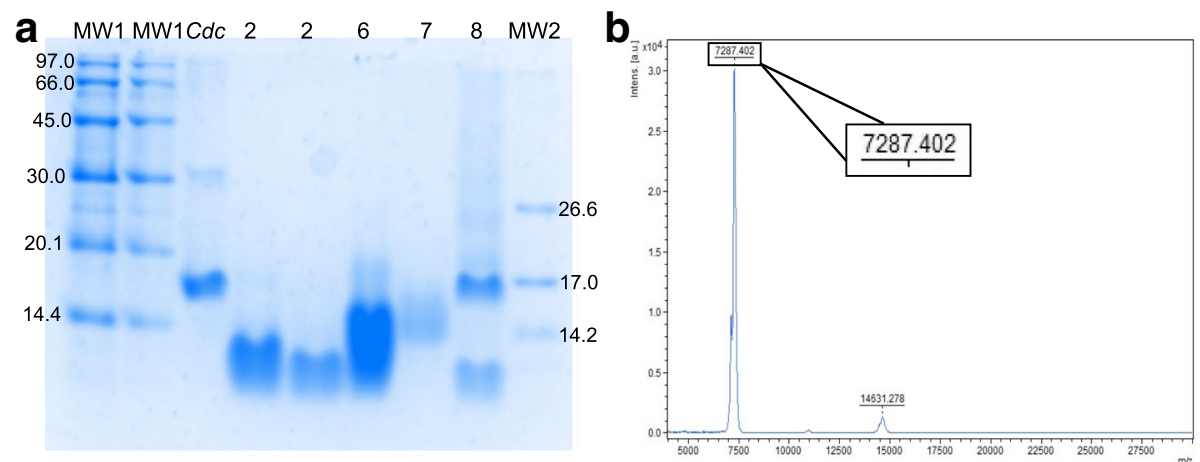

Fig. 2 Isolation profile of non-RGD disintegrin from C. d. collilineatus venom. a Tris-tricine-SDS-PAGE (16.5\%), in non-reduced conditions and the gel was stained with 0.2\% Coomassie Brilliant Blue G-250. MW1 - molecular mass (97.0-14.4 kDa); Cdc - C. d. collilineatus venom; 2 - Fraction 2 from RP-FPLC first step; 6-8 - fractions 6, 7 and 8, respectively, from RP-FPLC second step; MW2 - molecular mass (26.6-1.06 kDa). b Mass spectrum of Fraction 6 eluted from RP-FPLC second step obtained by MALDI-TOF (positive linear mode) using a-cyano-4-hydroxycinnamic acid (a-CHCA) matrix

compared to negative control), after $24 \mathrm{~h}$ of incubation (Fig. $4 \mathrm{~b}$ and c).

\section{Discussion}

In the present study, we aimed to perform the isolation, structural and functional characterization of a non-RGD disintegrin from $C$. $d$. collilineatus venom, which had never before been described. Only two chromatographic steps were sufficient to isolate non-RGD disintegrin. The choice of the methodology was based on previous venomic studies that had reported the presence of disintegrin in this subspecies venoms $[39,40]$.

Pure non-RGD disintegrin corresponds to $0.43 \%$ of soluble venom. This protein recovery is within the range of $0.4-0.5 \%$ of disintegrins in the venom of this subspecies determined by proteomic techniques [40]. Due to low amounts of disintegrins in snake venoms [40, 41], is necessary to produce recombinant disintegrins as similar to contortrostatin [42], r-colombistatins 2, 3, and 4 [43] and r-Cam-dis [44], among others.

Non-RGD disintegrin from $C$. d. collilineatus presents 7287.4 $\mathrm{Da}$, as determined by MALDI-TOF, and it is similar to the molecular mass of others snake venom disintegrins, such as tzabcanin $(7.1 \mathrm{kDa})$ [45], disintegrin from C. simus (7.1 kDa) [46] and proteomic data of $C . d$. collilineatus $[39,40]$.

As to the primary sequence obtained through Edman degradation and mass spectrometry procedures, $C d c$

a
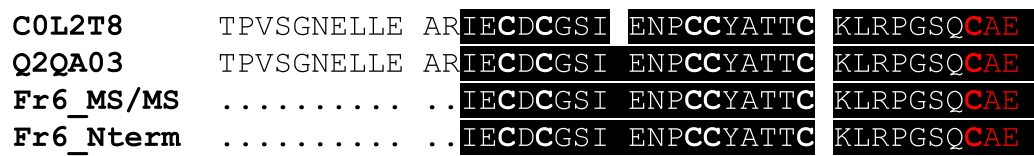

COL2T8

Q2QA03

Fr6 MS /MS

Fr6_Nterm

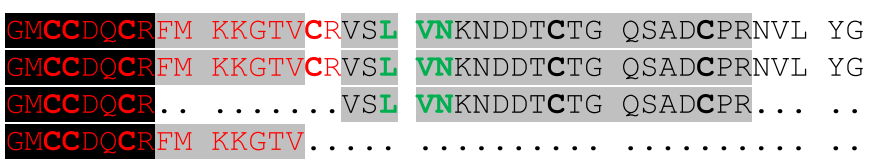

b

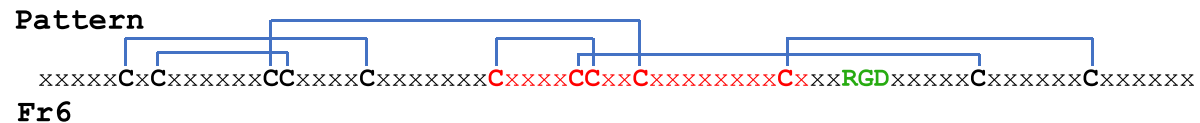

Fr6

.. IECDCGSIENPCCYATTCKLRPGSQCAEGMCCDQCRFMKKGTV. .VSLVNKNDDTCTGQSADCPR....

Fig. 3 Alignment and primary structure of disintegrins. a Sequence alignment between C. d. collilineatus (COL2T8) and C. d. durissus (Q2QA03) disintegrins, peptides determined by mass spectrometry analysis (Fr6_MS/MS) and sequence obtained by Edman degradation (Fr6_Nterm) of Fraction 6. b Comparison between the classical RGD disintegrin structure pattern and the determined primary structure of Fraction 6 (LVN disintegrin). Bold - cysteines ( ); Black box - consensus of all data sequence; Gray box - consensus of three data sequence; Red - pattern signature of disintegrin domain involving five conserved cysteines forming disulfide bonds; Green - RGD motif site; Blue - disulfide bond pattern of disintegrin structure; $x$ - any amino acid residue 
Table 2 Identification of non-RGD disintegrin peptides by MS/MS sequencing

\begin{tabular}{|c|c|c|c|c|c|c|}
\hline \multirow[t]{2}{*}{${ }^{\mathrm{a} M S / M S}$} & \multicolumn{3}{|l|}{ Peptide } & \multicolumn{3}{|l|}{ Protein } \\
\hline & $\mathrm{m} / \mathrm{z}$ & Z & Score & Access & Specie & Score \\
\hline NDDTCTGQSADCPR & 798.75 & 2 & 79 & Q2QA03 & C. d. durissus & 347 \\
\hline LRPGSQCAEGMCCDQCR & 695.23 & 3 & 64 & & & \\
\hline VSLVNKNDDTCTGQSADCPR & 746.27 & 3 & 100 & & & \\
\hline IECDCGSIENPCCYATTCK & 1169.36 & 2 & 105 & & & \\
\hline
\end{tabular}

${ }^{\mathrm{a} M S} / \mathrm{MS}$ : peptides identified by mass spectrometry using ESI

non-RGD disintegrin isolated in this study is absent from the classical RGD motif or any other motif previously observed in this protein family or glutamatecysteine-aspartate (ECD) motif which characterize disintegrin-like proteins that may inhibit tumor progression [47]. In the same position of this domain, this toxin presents a triad of amino acids LVN, which was found in disintegrins of $C$. $d$. collilineatus by transcriptome techniques [48], as well as in the disintegrin domains of P-II SVMP of $C$. $d$. collilineatus (COL2T8) and $C$. atrox (Q2QA03). On the other hand, these disintegrins, as well as that of our study, present the disulfide bond pattern of this protein family, another signature that characterizes disintegrins. This pattern of disulfide bonds has already been well reported and is closely related to the formation of the protein loop and activity. If disintegrins are reduced and alkylated their biological activity is decreased [49-53].

Disintegrins are known to be potent inhibitors of platelet aggregation, and some drugs based on its structure were developed and approved by the FDA [54], such as Eptifibatide [19] and Tirofiban [20]. The main mechanism for such inhibition is that the disintegrins bind to the $\alpha_{I I b} \beta_{3}$ platelet integrins, preventing their binding to fibrinogen and consequently inhibiting platelet aggregation [3]. Knowing that the integrins of platelets $\left(\alpha_{I I b} \beta_{3}\right)$ and breast cancer cells $\left(\alpha_{\mathrm{v}} \beta_{3}\right)$ are similar, disintegrins are considered candidates to be anticancer agents [2]. Integrins are transmembrane proteins, that are part of cell adhesion molecules (CAM) group, and

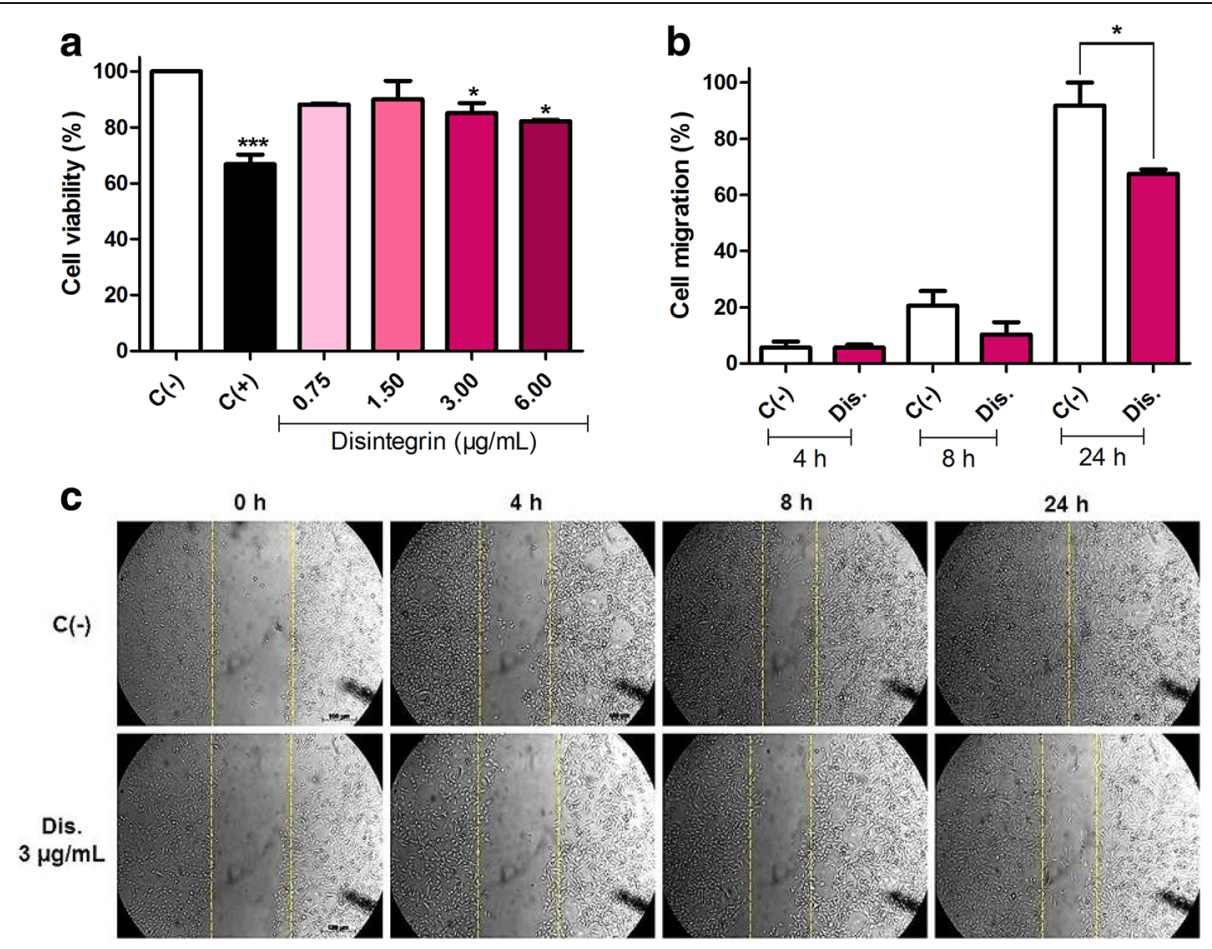

Fig. 4 Functional assays with MDA-MB-231 cells. a Cell viability (\%) after $24 \mathrm{~h}$ of treatment with disintegrin $(0.75-6.00 \mu \mathrm{g} / \mathrm{mL})$. C (-) - negative control (PBS); C (+) - positive control (MMS - $300 \mu \mathrm{M})$. The results were analyzed by ANOVA, followed by Dunett's post-hoc test $\left(^{*} p<0.05\right)$. $\mathbf{b}$ and c Cell migration after different times $(0,4,8$ and $24 \mathrm{~h}$ ) of treatment with non-RGD disintegrin (3 $\mu \mathrm{g} / \mathrm{mL})$. C (-) - negative control (PBS). The dashed yellow lines delimit the region where no cell growth is observed. Data $(n=3)$ are presented as mean \pm SD, which were analyzed by Student's $t$ test $\left({ }^{*} p<0.05\right)$ 
are formed by two subunits, $\alpha$, of approximately 120 to $180 \mathrm{kDa}$, and $\beta$, of approximately 90 to $110 \mathrm{kDa}$, non-covalently linked [55]. They are able to perform the cell-cell and cell-ECM interactions [56], and are essential for the development of tumor cells [57].

Since disintegrins are considered candidates to be agents of anticancer therapy, we performed cytotoxicity and cell migration assays on metastatic breast cancer cells, namely MDA-MB-231 cells. This cell line is able to express low levels of the subunits $\alpha_{2}$ and $\beta_{5}$ and moderate levels of $\alpha_{v}, \alpha_{3}$ and $\beta_{1}$ integrins [58]. Taherian et al. demonstrated that MDA-MB-231 cells express higher levels of $\beta_{5}$ and $\alpha_{v} \beta_{5}$ integrins when compared with non-breast cancer cell line (Hek-293) [59]. Our results show that non-RGD disintegrin from $C$. $d$. colilineatus venom presents low cytotoxicity, although its toxicity increases with the concentration, having a dose-response effect. As in our results, the tzabcanin also showed dose-dependent toxicity against human malignant melanoma (A-357) and human colorectal adenocarcinoma (Colo-205) cell lines, but the viabilities of human breast adenocarcinoma (MCF-7) and human lung adenocarcinoma (A-549) cell lines were not affected [45, 60]. Lebein inhibited the viability of human colon adenocarcinoma (HT29, LS174 and HCT116) and melanoma (SK-MEL-28 and LU-1205) cell lines [28, 61].

The cell migration assay showed that $C d c$ non-RGD disintegrin was able to inhibit the migration of MDA-MB-231 cells after $24 \mathrm{~h}$ of incubation, demonstrating that it is a possible anticancer agent with potential to inhibit the formation of breast cancer tumors. Similar results were obtained from tzabcanin, which inhibited cell migration of A-375 and A-549 cell lines [60], r-Viridistatin 2, from Crotalus viridis viridis, and r-mojastin 1, from Crotalus scutulatus scutulatus, that inhibited the migration of human pancreatic adenocarcinoma cancer cells (BXPC-3) [62].

In addition, considering the potential of disintegrins as anticancer therapeutic agents, they can also be used in combination with known chemotherapeutics. For example, echistatin combined with cisplatin (CDDP) was capable of increasing the expression of nuclear factor kappa B (NFkB), caspase-9 and caspase-3, leading to increased apoptosis in MDA-MB-231 cells. These data suggest that the combination of this disintegrin with CDDP may serve as a new type of anticancer therapy [63].

\section{Conclusion}

In this study, we described the isolation and characterization of the first disintegrin with an LVN motif from $C . d$. collilineatus venom. The studies performed on the human breast cancer MDA-MB-231 cell line demonstrate that this disintegrin is able to inhibit cell migration, without severely affecting cell viability.
Therefore, it may be a very useful molecular tool for understanding ECM-cell interaction cancer-related mechanisms involved important family of integrin that would elucidate molecular aspects of tumorigenesis. Also, this non-RGD disintegrin has potential to serve as an agent in anticancer therapy or adjuvant component combined with other anti-cancer drugs.

\section{Abbreviations}

ACN: Acetonitrile; ADP: Adenosine diphosphate; ANOVA: Analysis of variance; ATCC: American Type Culture Collection; BLAST: Basic Local Alignment Search Tool; CAM: Cell adhesion molecules; CDDP: Cisplatin;

DMEM: Dulbecco's Modified Eagle's Medium; DMSO: Dimethyl sulfoxide; ECD: Glutamate-cysteine-aspartate; ECM: Extracellular matrix; ESI: Electrospray; FDA: Food and Drug Administration; FPLC: Fast Protein Liquid

Chromatography; IBAMA: Brazilian Institute of the Environment and Renewable Natural Resources; KGD: Lysine-glycine-aspartic acid;

LVN: Leucine-valine-asparagine; MALDI: Matrix-assisted laser desorption/ ionization; MDC: Metalloprotease/disintegrin/cysteine-rich; MGD: Methionineglycine-aspartic acid; MLD: Methionine-leucine-aspartic acid; MMS: Methyl methanesulfonate; MS/MS: Tandem mass spectrometry; MTT: 3-[4, 5dimethylthiazol-2-yl]-2, 5 diphenyl tetrazolium bromide; MVD: Methioninevaline-aspartic acid; PBS: Phosphate buffered saline; Q-TOF: quadrupole-time of flight; RGD: Arginine-glycine-aspartic acid; SDS-PAGE: Sodium dodecyl sulfate polyacrylamide gel electrophoresis; SVMP: Snake venom metalloproteases; TFA: Trifluoroacetic acid; TOF: Time of flight; UPLC: Ultraperformance liquid chromatography; VGD: Valine-glycine-aspartic acid; WGD: Tryptophan-glycine-aspartic acid; a-CHCA: a-cyano-4-hydroxycinnamic acid

\section{Funding}

Financial support is from the Fundação de Amparo à Pesquisa do Estado de São Paulo (FAPESP, São Paulo Research Foundation, grant n. 2011/23236-4, 2012/14996-8, 2015/18432 and scholarships to ISO n. 2017/03580-9 and RVM n. 2016/11578-1) and Coordenação de Aperfeiçoamento de Pessoal de Nível Superior (CAPES, Coordination for the Improvement of Higher Education Personnel, Finance Code 001, scholarships to ARTM and IGF). Also, this work was supported in part by CAPES through Programa Editoração CAPES (edital n. 13/2016, auxílio n. 0722/2017, process n. 88881.142062/ 2017-01) and by Conselho Nacional de Desenvolvimento Científico e Tecnológico (CNPq, The National Council for Scientific and Technological Development) through Programa Editorial CNPq/CAPES (chamada n. 26/ 2017, process n. 440954/2017-7).

\section{Authors' contributions}

ISO was responsible for project development, designed the experimental approaches, interpreted the data and drafted the manuscript. RVM performed the experiments and participated in the data interpretation. IGF, IAC and KCFB participated in purification and structural characterization of disintegrin and in the data interpretation. ARTM and LMGA designed the functional assays, analyzed the data and participated in the data interpretation. JCR contributed with mass spectrometry analysis. ECA coordinated and designed all the experiments, analyzed and interpreted the data and was a major contributor in writing the manuscript. All authors read and approved the final manuscript.

Ethics approval and consent to participate Not applicable.

Consent for publication Not applicable.

\section{Competing interests}

The authors declare that they have no competing interests.

\section{Publisher's Note}

Springer Nature remains neutral with regard to jurisdictional claims in published maps and institutional affiliations. 


\section{Author details}

'School of Pharmaceutical Sciences of Ribeirão Preto, Department of Physics and Chemistry, University of São Paulo, Av. do Café s $/ n^{\circ}$, Monte Alegre, Ribeirão Preto, SP 14040-903, Brazil. ${ }^{2}$ Department of Clinical Analysis, Toxicology and Food Science, School of Pharmaceutical Sciences of Ribeirão Preto, University of São Paulo, Ribeirão Preto, SP, Brazil. ${ }^{3}$ Protein Chemistry Center and Department of Molecular and Cell Biology and Pathogenic Bioagents, School of Medicine of Ribeirão Preto, University of São Paulo, Ribeirão Preto, SP, Brazil.

\section{Received: 6 July 2018 Accepted: 5 October 2018} Published online: 20 October 2018

\section{References}

1. Kini RM, Evans HJ. Structural domains in venom proteins: evidence that metalloproteinases and nonenzymatic platelet aggregation inhibitors (disintegrins) from snake venoms are derived by proteolysis from a common precursor. Toxicon. 1992;30(3):265-93.

2. Calvete JJ. The continuing saga of snake venom disintegrins. Toxicon. 2013; 62:40-9.

3. Huang TF, Holt JC, Lukasiewicz H, Niewiarowski S. Trigramin. A low molecular weight peptide inhibiting fibrinogen interaction with platelet receptors expressed on glycoprotein IIb-IIla complex. J Biol Chem. 1987; 262(33):16157-63.

4. Gould RJ, Polokoff MA, Friedman PA, Huang TF, Holt JC, Cook JJ, et al. Disintegrins: a family of integrin inhibitory proteins from viper venoms. Proc Soc Exp Biol Med. 1990;195(2):168-71.

5. Selistre-de-Araujo HS, Pontes CLS, Montenegro CF, Martin ACBM. Snake venom disintegrins and cell migration. Toxins (Basel). 2010;2(11):2606-21.

6. Sanchez EF, Flores-Ortiz RJ, Alvarenga VG, Eble JA. Direct fibrinolytic snake venom metalloproteinases affecting hemostasis: structural, biochemical features and therapeutic potential. Toxins (Basel). 2017:9:12.

7. Calvete JJ, Jürgens M, Marcinkiewicz C, Romero A, Schrader M, Niewiarowski S. Disulphide-bond pattern and molecular modelling of the dimeric disintegrin EMF-10, a potent and selective integrin $\alpha_{5} \beta_{1}$ antagonist from Eristocophis macmahoni venom. Biochem J. 2000;345(3):573-81.

8. Bilgrami S, Yadav S, Kaur P, Sharma S, Perbandt M, Betzel C, et al. Crystal structure of the disintegrin heterodimer from saw-scaled viper (Echis carinatus) at 1.9 a resolution. Biochemistry. 2005:44(33):11058-66.

9. Bilgrami S, Tomar S, Yadav S, Kaur P, Kumar J, Jabeen T, et al. Crystal structure of schistatin, a disintegrin homodimer from saw-scaled viper (Echis carinatus) at 2.5 a resolution. J Mol Biol. 2004:341(3):829-37.

10. Calvete JJ, Moreno-Murciano MP, Theakston RD, Kisiel DG, Marcinkiewicz C. Snake venom disintegrins: novel dimeric disintegrins and structural diversification by disulphide bond engineering. Biochem J. 2003;372(Pt 3): 725-34

11. Juárez P, Comas I, González-Candelas F, Calvete JJ. Evolution of snake venom disintegrins by positive Darwinian selection. Mol Biol Evol. 2008; 25(11):2391-407

12. Sanz L, Bazaa A, Marrakchi N, Pérez A, Chenik M, Bel Lasfer Z, et al. Molecular cloning of disintegrins from Cerastes vipera and Macrovipera lebetina transmediterranea venom gland cDNA libraries: insight into the evolution of the snake venom integrin-inhibition system. Biochem J. 2006; 395(2):385-92

13. Calvete JJ, Juárez P, Sanz L. Snake venomics and disintegrins: portrait and evolution of a family of snake venom integrin antagonists. In: Mackessy SP editor. Handbook of venoms and toxins of reptiles. Boca Ratón: CRC Press, Taylor \& Francis; 2009. p. 337-57.

14. Calvete JJ. Brief history and molecular determinants of snake venom disintegrin evolution. In: Kini RM, Markland F, McLane MA, Morita T, editors. Toxins and hemostasis: from bench to bedside. Amsterdam: Springer; 2010. p. 285-300

15. Oshikawa K, Terada S. Ussuristatin 2, a novel KGD-bearing disintegrin from Agkistrodon ussuriensis venom. J Biochem. 1999:125(1):31-5.

16. Scarborough RM, Rose JW, Hsu MA, Phillips DR, Fried VA, Campbell AM, et al. Barbourin. A GPIllb-llla-specific integrin antagonist from the venom of Sistrurus m. barbouri. J Biol Chem. 1991;266(15):9359-62.

17. Hite LA, Shannon JD, Bjarnason JB, Fox JW. Sequence of a CDNA clone encoding the zinc metalloproteinase hemorrhagic toxin e from Crotalus atrox: evidence for signal, zymogen, and disintegrin-like structures. Biochemistry. 1992;31(27):6203-11.
18. King GF. Venoms as a platform for human drugs: translating toxins into therapeutics. Expert Opin Biol Ther. 2011:11(11):1469-84.

19. O'Shea JC, Tcheng JE. Eptifibatide: a potent inhibitor of the platelet receptor integrin glycoprotein Ilb/Illa. Expert Opin Pharmacother. 2002;3(8):1199-210.

20. Menozzi A, Merlini PA, Ardissino D. Tirofiban in acute coronary syndromes. Expert Rev Cardiovasc Ther. 2005:3(2):193-206.

21. Arruda Macêdo JK, Fox JW, de Souza Castro M. Disintegrins from snake venoms and their applications in cancer research and therapy. Curr Protein Pept Sci. 2015;16(6):532-48.

22. Zhou Q, Sherwin RP, Parrish C, Richters V, Groshen SG, Tsao-Wei D, et al. Contortrostatin, a dimeric disintegrin from Agkistrodon contortrix contortrix, inhibits breast cancer progression. Breast Cancer Res Treat. 2000:61(3):249-60.

23. Kim KS, Kim DS, Chung KH, Park YS. Inhibition of angiogenesis and tumor progression by hydrodynamic cotransfection of angiostatin K1-3, endostatin and saxatilin genes. Cancer Gene Ther. 2006;13(6):563-71.

24. Higuchi DA, Almeida MC, Barros CC, Sanchez EF, Pesquero PR, Lang EA, et al. Leucurogin, a new recombinant disintegrin cloned from Bothrops leucurus (white-tailed-jararaca) with potent activity upon platelet aggregation and tumor growth. Toxicon. 2011;58(1):123-9.

25. Wang JH, Wu Y, Ren F, Lü L, Zhao BC. Cloning and characterization of Adinbitor, a novel disintegrin from the snake venom of Agkistrodon halys brevicaudus stejneger. Acta Biochim Biophys Sin Shanghai. 2004;36(6):425-9.

26. Tian J, Paquette-Straub C, Sage EH, Funk SE, Patel V, Galileo D, et al. Inhibition of melanoma cell motility by the snake venom disintegrin eristostatin. Toxicon. 2007:49(7):899-908

27. Galán JA, Sánchez EE, Rodríguez-Acosta A, Soto JG, Bashir S, McLane MA, et al. Inhibition of lung tumor colonization and cell migration with the disintegrin crotatroxin 2 isolated from the venom of Crotalus atrox. Toxicon. 2008:51(7):1186-96

28. Zakraoui O, Marcinkiewicz C, Aloui Z, Othman H, Grépin R, Haoues M, et al. Lebein, a snake venom disintegrin, suppresses human colon cancer cells proliferation and tumor-induced angiogenesis through cell cycle arrest, apoptosis induction and inhibition of VEGF expression. Mol Carcinog. 2017; 56(1):18-35

29. Desgrosellier JS, Cheresh DA. Integrins in cancer: biological implications and therapeutic opportunities. Nat Rev Cancer. 2010;10(1):9-22.

30. Chavez KJ, Garimella SV, Lipkowitz S. Triple negative breast cancer cell lines: one tool in the search for better treatment of triple negative breast cancer. Breast Dis. 2010;32(1-2):35-48.

31. Zhao F, Li L, Guan L, Yang H, Wu C, Liu Y. Roles for GP IIb/llla and $a_{v} \beta_{3}$ integrins in MDA-MB-231 cell invasion and shear flow-induced cancer cell mechanotransduction. Cancer Lett. 2014:344(1):62-73.

32. Calvete JJ, Juarez P, Sanz L. Snake venomics. Strategy and applications. J Mass Spectrom. 2007:42:1405-14.

33. Shagger $H$, von Jagow G. Tricine-SDS-PAGE for the separation of proteins in the 1-100 kDa range. Anal Biochem. 1987;168:368-79.

34. Edman P, Begg G. A protein sequenator. Eur J Biochem. 1967;1(1):80-91.

35. Altschul SF, Gish W, Miller W, Myers EW, Lipman DJ. Basic local alignment search tool. J Mol Biol. 1990;215(3):403-10.

36. The UniProt Consortium. UniProt: the universal protein knowledgebase. Nucleic Acids Res. 2017;45:D158-69.

37. Mosmann T. Rapid colorimetric assay for cellular growth and survival: application to proliferation and cytotoxicity assays. J Immunol Methods. 1983;65(1-2):55-63.

38. Liang CC, Park AY, Guan JL. In vitro scratch assay: a convenient and inexpensive method for analysis of cell migration in vitro. J Immunol Methods. 1983;65:55-63.

39. Oliveira IS, Cardoso IA, KCF B, Carone SEl, Boldrini-França J, Pucca MB, et al. Global proteomic and functional analysis of Crotalus durissus collilineatus individual venom variation and its impact on envenoming. J Proteome. 2018

40. Boldrini-Franca J, Corrêa-Netto C, Silva MMS, Rodrigues RS, De La Torre P, Perez A, et al. Snake venomics and antivenomics of Crotalus durissus subspecies from Brazil: assessment of geographic variation and its implication on snakebite management. J Proteome. 2010;73(9):1758-76.

41. Nicolau CA, Carvalho PC, Junqueira-de-Azevedo IL, Teixeira-Ferreira A, Junqueira $M$, Perales J, et al. An in-depth snake venom proteopeptidome characterization: benchmarking Bothrops jararaca. J Proteome. 2017;151: 214-31.

42. Zhou Q, Hu P, Ritter MR, Swenson SD, Argounova S, Epstein AL, et al. Molecular cloning and functional expression of contortrostatin, a 
homodimeric disintegrin from southern copperhead snake venom. Arch Biochem Biophys. 2000;375(2):278-88.

43. Suntravat M, Helmke TJ, Atphaisit C, Cuevas E, Lucena SE, Uzcátegui NL, et al. Expression, purification, and analysis of three recombinant ECD disintegrins (r-colombistatins) from P-III class snake venom metalloproteinases affecting platelet aggregation and SK-MEL-28 cell adhesion. Toxicon. 2016;122:43-9.

44. Suntravat M, Barret HS, Jurica CA, Lucena SE, Perez JC, Sánchez EE. Recombinant disintegrin ( $r$-cam-dis) from Crotalus adamanteus inhibits adhesion of human pancreatic cancer cell lines to laminin-1 and vitronectin. J Venom Res. 2015;6:1-10.

45. Saviola AJ, Modahl CM, Mackessy SP. Disintegrins of Crotalus simus tzabcan venom: isolation, characterization and evaluation of the cytotoxic and antiadhesion activities of tzabcanin, a new RGD disintegrin. Biochimie. 2015;116: 92-102.

46. Angulo Y, Castro A, Lomonte B, Rucavado A, Fernández J, Calvete JJ, et al. Isolation and characterization of four medium-size disintegrins from the venoms of central American viperid snakes of the genera Atropoides, Bothrops, Cerrophidion and Crotalus. Biochimie. 2014;107(Pt B):376-84.

47. Moritz MNO, Eustáquio LMS, Micocci KC, Nunes ACC, Dos Santos PK, de Castro Vieira $T$, et al. Alternagin-C binding to $a_{2} \beta_{1}$ integrin controls matrix metalloprotease- 9 and matrix metalloprotease- 2 in breast tumor cells and endothelial cells. J Venom Anim Toxins incl Trop Dis. 2018;24:13. https://doi. org/10.1186/s40409-018-0150-2

48. Boldrini-França J, Rodrigues RS, Fonseca FP, Menaldo DL, Ferreira FB, HenriqueSilva F, et al. Crotalus durissus collilineatus venom gland transcriptome: analysis of gene expression profile. Biochimie. 2009;91(5):586-95.

49. Calvete JJ, Schäfer W, Soszka T, Lu WQ, Cook JJ, Jameson BA, et al. Identification of the disulfide bond pattern in albolabrin, an RGD-containing peptide from the venom of Trimeresurus albolabris: significance for the expression of platelet aggregation inhibitory activity. Biochemistry. 1991; 30(21):5225-9.

50. Huang TF, Holt JC, Kirby EP, Niewiarowski S. Trigramin: primary structure and its inhibition of von Willebrand factor binding to glycoprotein IIb/Illa complex on human platelets. Biochemistry. 1989;28(2):661-6.

51. Knudsen KA, Tuszynski GP, Huang TF, Niewiarowski S. Trigramin, an RGDcontaining peptide from snake venom, inhibits cell-substratum adhesion of human melanoma cells. Exp Cell Res. 1988;179(1):42-9.

52. Saudek V, Atkinson RA, Lepage P, Pelton JT. The secondary structure of echistatin from $1 \mathrm{H}-\mathrm{NMR}$, circular-dichroism and Raman spectroscopy. Eur J Biochem. 1991;202(2):329-38.

53. Calvete JJ, Wang Y, Mann K, Schäfer W, Niewiarowski S, Stewart GJ. The disulfide bridge pattern of snake venom disintegrins, flavoridin and echistatin. FEBS Lett. 1992;309(3):316-20,

54. Chan YS, Cheung RCF, Xia L, Wong JH, Ng TB, Chan WY. Snake venom toxins: toxicity and medicinal applications. Appl Microbiol Biotechnol. 2016; 100(14):6165-81.

55. Ferraz FB, Fernandez JF. Integrinas na adesão, migração e sinalização celular: associação com patologias e estudos clínicos. Revista Científica da FMC. 2014;9(2):25-34 http://www.fmc.br/revista/N9N2P25-34.pdf.

56. Hou S, Isaji T, Hang Q, Im S, Fukuda T, Gu J. Distinct effects of $\beta_{1}$ integrin on cell proliferation and cellular signaling in MDA-MB-231 breast cancer cells. Sci Rep. 2016;6:18430.

57. Jin $\mathrm{H}$, Varner J. Integrins: roles in cancer development and as treatment targets. Br J Cancer. 2004;90(3):561-5.

58. Gui GP, Puddefoot JR, Vinson GP, Wells CA, Carpenter R. In vitro regulation of human breast cancer cell adhesion and invasion via integrin receptors to the extracellular matrix. Br J Surg. 1995;82(9):1192-6.

59. Taherian A, Li X, Liu Y, Haas TA. Differences in integrin expression and signaling within human breast cancer cells. BMC Cancer. 2011;11:293.

60. Saviola AJ, Burns PD, Mukherjee AK, Mackessy SP. The disintegrin tzabcanin inhibits adhesion and migration in melanoma and lung cancer cells. Int J Biol Macromol. 2016;88:457-64.

61. Hammouda MB, Montenegro MF, Sánchez-del-Campo L, Zakraoui O, Aloui Z, Riahi-Chebbi I, et al. Lebein, a snake venom disintegrin, induces apoptosis in human melanoma cells. Toxins (Basel). 2016;8(7):1-14.

62. Lucena S, Castro R, Lundin C, Hofstetter A, Alaniz A, Suntravat M, et al. Inhibition of pancreatic tumoral cells by snake venom disintegrins. Toxicon. 2015;93:136-43.

63. Czarnomysy R, Surażyński A, Popławska B, Rysiak E, Pawłowska N, Czajkowska A, et al. Synergistic action of cisplatin and echistatin in MDAMB-231 breast cancer cells. Mol Cell Biochem. 2017;427(1):13-22.

\section{Ready to submit your research? Choose BMC and benefit from}

- fast, convenient online submission

- thorough peer review by experienced researchers in your field

- rapid publication on acceptance

- support for research data, including large and complex data types

- gold Open Access which fosters wider collaboration and increased citations

- maximum visibility for your research: over $100 \mathrm{M}$ website views per year

At $\mathrm{BMC}$, research is always in progress.

Learn more biomedcentral.com/submissions 